\title{
ASPEK HUKUM PEMBERDAYAAN MASYARAKAT DI SEKITAR HUTAN LINDUNG PULAU TARAKAN
}

(Legal Aspects of Community Empowerment in Protected Forest Area of Tarakan Island)

\author{
Aditia Syaprillah \\ Fakultas Hukum Universitas Borneo Tarakan \\ Email: didit_syaprillah@yahoo.co.id
}

Naskah diterima: 1 Juni 2015; revisi: 12 Agustus 2015; disetujui: 19 Agustus 2015

\begin{abstract}
Abstrak
Kota Tarakan merupakan kota di atas pulau dengan luas daratan hanya mencapai $\pm 250.80 \mathrm{~km}^{2}$, kebutuhan terhadap lahan perkebunan dan pemukiman menjadi salah satu penyebab terjadinya permasalahan degradasi kawasan hutan, kondisi ini diperparah dengan semakin pesatnya perkembangan jumlah penduduk di Kota Tarakan. Berdasarkan permasalahan di atas, maka perlu melakukan penelitian hukum tentang pemberdayaan masyarakat setempat di sekitar hutan lindung pulau Tarakan. Penelitian ini menggunakan metode penelitian normatif dengan pendekatan perundang-undangan (Statute Approach) yang menelaah peraturan yang terkait dengan isu hukum yang sedang ditangani. Hasil penelitian menunjukan bahwa kegiatan pemberdayaan masyarakat disekitar hutan lindung Pulau Tarakan mempunyai peran yang sangat strategis dalam pencegahan dan pemberantasan kerusakan hutan serta untuk menjaga kelestarian hutan lindung pulau Tarakan, hal tersebut perlu ditunjang dengan perubahan pendekatan melalui pemberian akses dan pelibatan masyarakat dalam setiap kebijakan. Untuk itu disarankan perlu adanya peraturan daerah yang lebih responsif untuk melindungi setiap hakhak dan jaminan sosial dan ekonomi masyarakat yang ada di dalam wilayah hutan lindung Pulau Tarakan.
\end{abstract}

Kata Kunci: pemberdayaan, lahan, Tarakan

\section{Abstract}

Tarakan city is a city on the island with a land area only reached $\pm 250.80 \mathrm{~km}^{2}$, the need for plantations and settlements is one of the causes of forest degradation problems, the condition is exacerbated by the rapid growth of population in the city of Tarakan. Based on the above problems, it is necessary to conduct legal research on empowering communities around protected forests area of Tarakan. This study uses normative method and statute approach that examines regulations related to legal issues that are being addressed. The research showed that the activities of the empowerment of communities around the protected forest area of Tarakan Island has a very strategic role in the prevention and eradication of forest damage and to preserve the protected forests of Tarakan Island, it needs to be supported by a change of approach by providing communities access and involvement in every policy. It is suggested that there needs to be more responsive local regulations to protect every rights and social and economic security of communities in the protected forest area of Tarakan Island.

Keyword: empowerment, land, Tarakan 


\section{A. Pendahuluan}

Hutan merupakan salah satu kekayaan alam terbesar yang dimiliki oleh bangsa Indonesia. Hutan menjadi modal pembangunan nasional dan penghidupan bangsa Indonesia, baik manfaat ekologi, sosial budaya maupun ekonomi, secara seimbang dan dinamis. Untuk itu hutan harus diurus dan dikelola, dilindungi dan dimanfaatkan secara berkesinambungan bagi kesejahteraan masyarakat Indonesia, baik generasi sekarang maupun yang akan datang. ${ }^{1}$ Dalam rangka mewujudkan hal tersebut, maka diperlukan asas pembangunan kehutanan yang berkeadilan dan berkelanjutan (just and sustainable yield principle). Asas ini meletakan masyarakat sebagai subyek dalam kegiatan pengelolaan hutan secara aktif dan intrasistem. ${ }^{2}$

Undang-Undang Nomor 41 Tahun 1999 tentang Kehutanan (selanjutnya disingkat UU Kehutanan 1999) yang lahir dalam semangat reformasi mencoba memasukkan ketentuan yang memberikan ruang kepada masyarakat untuk terlibat dalam pengelolaan hutan. Hal tersebut dapat dilihat pada konsideran menimbang huruf $c$ yang menyatakan:

"bahwa pengurusan hutan yang
berkelanjutan dan berwawasan mendunia,
harus menampung dinamika aspirasi dan
peran serta masyarakat, adat dan budaya,
serta tata nilai masyarakat yang berdasarkan
pada norma hukum nasional".

Pembangunan hutan berkelanjutan memerlukan upaya yang sungguh-sungguh karena masih terjadi berbagai tindak kejahatan kehutanan seperti pembalakan liar, penambangan tanpa izin, dan perkebunan tanpa izin. Kejahatan itu telah menimbulkan kerugian Negara dan kerusakan kehidupan sosial budaya dan lingkungan hidup yang sangat besar serta telah meningkatkan pemanasan global yang telah menjadi isu nasional, regional dan internasional. ${ }^{3}$

Berdasarkan Peraturan Daerah Kota Tarakan Nomor 4 Tahun 2012 tentang Rencana Tata Ruang Wilayah (RTRW) Kota Tarakan, total luasan kawasan lindung di Tarakan mencapai 11.742,99 ha atau mencukupi sekitar 46,82 persen. Dari luasan tersebut, terdapat hutan lindung seluas $6.997,22$ ha dan sisanya adalah Ruang Terbuka Hijau (RTH) yang terdiri dari hutan mangrove (1.119,30 ha), hutan kota $(2.390,48 \mathrm{ha})$, taman kota (1,07 ha), sabuk hijau (682,60 ha) tempat pemakaman umum $(67,28 \mathrm{ha})$, stadion olahraga (3,00 ha), kawasan perlindungan setempat (465,70 ha), dan sumber air baku (15,34 ha). Untuk lebih jelasnya dapat dilihat dalam tabel berikut ini:

Penjelasan Umum Alinea 2 Undang-Undang Nomor 41 Tahun 1999 tentang Kehutanan.

Ahmad Ubbe et al., Penelitian Hukum Tentang Peran Serta Masyarakat Hukum Adat Dalam Penanggulangan Pembalakan Liar, (Jakarta: Pusat Penelitian dan Pengembangan Sistem Hukum Nasional, Badan Pembinaan Hukum Nasional Kementerian Hukum dan Hak Asasi Manusia RI, 2013), hlm. 2.

3 Penjelasan Umum Alinea 4 Undang-Undang Nomor 18 Tahun 2013 tentang Pencegahan Pemberantasan Perusakan Hutan. 
Tabel 1 Total Luasan Kawasan Lindung Kota Tarakan

\begin{tabular}{|c|c|c|}
\hline \multicolumn{3}{|c|}{ KAWASAN LINDUNG } \\
\hline 1 & HUTAN LINDUNG & $6.997,22$ hektare \\
\hline 2 & RUANG TERBUKA HIJAU & \\
\hline & - Hutan Mangrove & $1.119,30$ hektare \\
\hline & - Hutan Kota & 2.390,48 hektare \\
\hline & - Taman Kota & 1,07 hektare \\
\hline & - Sabuk Hijau & 682,60 hektare \\
\hline & $\begin{array}{l}\text { - Tempat Pemakaman } \\
\text { Umum }\end{array}$ & 67,28 hektare \\
\hline & - Stadion Olahraga & 3,00 hektare \\
\hline & $\begin{array}{l}\text { - Kawasan Perlindungan } \\
\text { Setempat }\end{array}$ & 465,70 hektare \\
\hline & - Sumber Air Baku & 16,34 hektare \\
\hline & Total & 11.742,99 hektare \\
\hline
\end{tabular}

Sumber: Peraturan Daerah Kota Tarakan Nomor 4 Tahun 2012 tentang Rencana Tata Ruang Wilayah (RTRW) Kota Tarakan

Kota Tarakan yang merupakan kota pulau dengan luas daratan hanya mencapai \pm $250.80 \mathrm{~km}^{2}$, permasalahan kebutuhan lahan juga menjadi salah satu penyebab terjadinya degradasi pada kawasan hutan. Keinginan untuk melestarikan hutan oleh pemerintah daerah seringkali berbenturan dengan berbagai kepentingan untuk meningkatan pelayanan bagi masyarakat secara umum, kondisi ini diperparah dengan semakin pesatnya perkembangan jumlah penduduk di Kota Tarakan yang mencapai $6,78 \%$ per tahun sehingga kemudian memunculkan berbagai isu lingkungan yang perlu segera dicermati diantaranya banjir dan tanah longsor, pemenuhan kebutuhan air bersih, serta pencemarana udara dan air. Kesadaran dan komitmen yang kuat dari pemerintah daerah akan pentingnya melestarikan kawasan hutan sebagai dari upaya untuk mengatasi berbagai isu lingkungan tersebut diatas merupakan faktor penting dalam mendukung berbagai kegiatan konservasi dan rehabilitasi pada kawasan hutan serta mewujudkan pembangunan berkelanjutan di Kota Tarakan. ${ }^{4}$

Berdasarkan fakta dipeta dan dilapangan dalam penetapan Rencana Tata Ruang Wilayah yang selanjutnya disingkat RTRW. Salah satunya, pada sejumlah lokasi yang ditetapkan sebagai hutan kota, ada kawasan yang telah dikuasai masyarakat hingga berpuluh tahun lamanya. Penguasaan lahan itu baik untuk perkebunan maupun perumahan/permukiman (tumpang tindih status lahan). Adapun kawasan lindung yang di dalamnya terdapat lahan yang dikuasai warga, kebanyakan berada di wilayah Resort Timur (Kecamatan Tarakan Timur), tepatnya di RT 2, RT 3, RT 4, RT 5, RT 11 dan RT 8 daerah Karungan, Kelurahan Mamburungan; Mamburungan Timur dan Pantai Amal. Uniknya, lahan yang dimiliki warga tersebut dilandasi dengan alas hak yang legal secara hukum, seperti Surat Izin Menggunakan Tanah Negara (SIMTN), bahkan ada diantara mereka yang sudah membayar Pajak Bumi dan Bangunan (PBB). "Jadi wilayah disana, bukan lagi hutan namun kebun dan itu dapat dibuktikan dengan dasar bahwa di lokasi itu tumbuh tanaman yang usianya puluhan tahun. ${ }^{5}$ Di Kecamatan Tarakan Tengah juga terdapat permasalahan tenurial (klaim atas hak) di wilayah Resort Tengah (Kecamatan Tarakan Tengah), utamanya pada kelurahan Kampung I/Skip pemukiman RT 9,

4 Dinas Kehutanan, Pertambangan \& Energi Kota Tarakan, Lembaga Penelitian dan Pengabdian Kepada Masyarakat (LPPM) UBT, Tata Hutan Wilayah Kelola KPHL Tarakan (Tarakan: Kerjasama antara Dinas Kehutanan, Pertambangan \& Energi Kota Tarakan dengan Lembaga Penelitian dan Pengabdian Kepada Masyarakat (LPPM) UBT, 2011), hlm. 1-2.

5 Radar Tarakan, “RTRW Tarakan Tak Sesuai Fakta. Banyak Lahan Warga yang Masuk Kawasan Hutan Kota”, (Rabu, 23 Oktober 2013). 
RT 10, RT 18, dan RT 20.Secara garis besar, di setiap RT tersebut, terdapat banyak bangunan permanen dan semi permanen yang tak sepantasnya ada di kawasan lindung diwilayah Kelurahan Kampung 1/Skip. ${ }^{6}$

Salah satu solusi untuk menekan ancaman dan gangguan tersebut adalah melalui pemberdayaan masyarakat disekitar kawasan konservasi. Ini merupakan langkah tepat untuk menanggulangi masalah tersebut, karena pemberdayaan masyarakat bertujuan antara lain untuk meningkatkan kemampuan dan kemandirian masyarakat serta meningkatkan kesejahteraan masyarakat dan memberikan akses bagi masyarakat lokal dan adat dalam pemanfaatan potensi kawasan sesuai dengan prinsip-prinsip kelestarian.

Berdasarkan uraian latar belakang di atas, maka perlu untuk melakukan penelitian hukum tentang pemberdayaan masyarakat setempat di sekitar hutan lindung pulau Tarakan sebagai solusi dari permasalahan yang telah penulis uraikan di atas. Dan dapat memberikan kesempatan kepada masyarakat setempat untuk bersama-sama ikut mengelola sumber daya hutan lindung di Pulau Tarakan.

\section{B. Metode Penelitian}

Pendekatan masalah yang digunakan dalam penulisan ini adalah metode penelitian normatif atau dengan pendekatan perundang-undangan (Statute Approach), ${ }^{7}$. Pendekatan perundangundangan (Statuta Approach) dilakukan dengan menelaah semua udang-undang dan regulasi yang bersangkut paut dengan isu hukum yang sedang ditangani. Dengan menggunakan bahan hukum hukum primer dan bahan hukum sekunder.

Prosedur pengumpulan bahan hukum, dilakukan melalui studi pustaka, yang diawali dengan melakukan inventarisasi bahan hukum, mengklasifikasi bahan hukum, dan membaca secara sistematis terhadap bahan hukum yang tersedia, yang digunakan sebagai pedoman untuk menjawab rumusan masalah yang ada, dan di dalam melakukan analisa penulis menggunakan metode interpretasi, yaitu metode penelitian yang diawali dari pendapat yang ada dalam masalah-masalah tersebut diinterpretasikan melalui penafsiran secara bahasa, undang-undang atau secara sistematis tentang masalah yang akan dibahas, dengan melihat konsep hukum dari sudut pandang normatif.

\section{Pembahasan}

\section{Konsep Pemberdayaan Masyarakat}

Proses pemberdayaan hendaknya lebih menekankan kepada proses memberikan atau mengalihkan sebagian kekuatan, kekuasaan atau kemampuan kepada masyarakat agar lebih berdaya dan mendorong atau memotivasi individu sehingga mempunyai kemampuan atau keberdayaan untuk menentukan apa yang menjadi pilihan hidupnya melalui proses dialog. ${ }^{8}$ Selanjutnya pemberdayaan hanya dapat dilakukan melalui proses partisipasi. ${ }^{9}$

Radar Tarakan, “Batas Wilayah Kelola Belum Diakui”, (Jum'at, 8 November 2013).

Piter Mahmud Marzuki, Penelitian Hukum, (Jakarta: Penerbit Prenada Media, 2005), hlm. 93.

Esmi Warasih, "Pemberdayaan Masyarakat Dalam Mewujudkan Tujuan Hukum (Proses Penegakan Hukum dan Persoalan Keadilan)" (Pidato disampaikan pada Pengukuhan Guru Besar Madya Dalam Ilmu Hukum Pada Fakultas Hukum Universitas Diponegoro, Semarang, 14 April 2001), hlm. 28.

$9 \quad$ Ibid. 
Menurut Sherry R. Arnstein, partisipasi dibagi ke dalam tiga tingkatan, yaitu: ${ }^{10}$ Non Participative, Tokenism dan Citizen Participative. Tingkatan pertama meliputi manipulasi dan terapi, artinya bukan partisipasi sebab tujuannya bukan memberikan kemampuan pada masyarakat agar berperan serta membuat keputusan melainkan mendidik dan mengobati partisipan dalam proses partisipasi; sedangkan tingkatan kedua meliputi informing, consultation dan placation yang merupakan formalitas belaka sebab aspirasi, pendapat atau opini partisipan hanya sebagai bahan untuk di dengar yang belum tentu menjadi bahan pengambilan keputusan; tingkatan ketiga terdiri atas partnership, delegate power dan citizen control, masyarakat dapat melakukan negosiasi dan bahkan memiliki kekuatan untuk ikut serta dalam pengambilan keputusan, dan yang terakhir inilah yang merupakan partisipasi nyata.

Peran serta masyarakat dalam proses menyatakan pendapat dapat berupa dengar pendapat, pernyataan keberatan dan lain sikap dalam proses pengambilan keputusan izin. Hal ini sesuai dengan budaya masyarakat terhadap hukum dan sistem hukum, people's attitude towardslawandlegalsystem sebagaimana ditulis oleh Lawrence M. Friedman. ${ }^{11}$ Keberadaan suatu masyarakat di sebuah wilayah diharapkan dapat membantu lembaga pemerintah dalam merumuskan sebuah pengaturan yang dimana pengaturan itu memuat pikiran, ide dan harapan masyarakat sehingga apa yang sudah dirumuskan tersebut dapat dijalankan dan diawasi secara efektif bersama-sama dengan masyarakat dan pemerintah.

Menurut Koesnadi Hardjasoemantri, pokok pikiran yang melandasi perlunya peran serta masyarakat dapat dikemukakan sebagai berikut: ${ }^{12}$

a. Memberi Informasi kepada Pemerintah

Peran serta masyarakat terutama akan dapat menambah perbendaharaan pengetahuan mengenai sesuatu aspek tertentu yang diperoleh dari pengetahuan khusus masyarakat itu sendiri maupun dari para ahli yang dimintai pendapat oleh masyarakat. Peran serta masyarakat sangat diperlukan untuk memberi masukan kepada Pemerintah tentang masalah yang dapat ditimbulkan oleh sesuatu rencana Pemerintah dengan berbagai konsekuensinya. Dan informasi yang didapatkan dari masyarakat akan menambah informasi dan masukan bagi proses pengambilan keputusan yang dilakukan

10 Sherry R. Arnstein, A Ladder of Citizen Participation, Classic Readings in Urban Planning: An Introduction, yang dikutip oleh Esmi Warasih, Ibid, hlm. 29.

11 Menurut Lawrence M. Friedman ada 3 (tiga) elemen atau aspek dari sistem hukum, yaitu: structure, subtance, dan legal culture. Structure menyangkut lembaga-lembaga yang berwenang membuat dan melaksanakan undangundang (eksekutif dan legislatif), subtance, yaitu materi atau bentuk dari peraturan perundang-undangan yang terbagi dalam hukum tertulis/kodifikasi dan common law system, sedangkan legal culture dimaksudkan sebagai sikap orang terhadap hukum dan sistem hukum, yaitu menyangkut kepercayaan akan nilai, pikiran atau ide dan harapan mereka people's attitude towards law and the legal system, their beliefs, values, ideas and expectations. Lebih lanjut lihat T. Gayus Lumbun, Peran Masyarakat Dalam Pengelolaan Lingkungan Hidup, (dalam Hukum dan Lingkungan Hidup di Indonesia 75 Tahun Prof. Dr. Koesnadi Hardjasoemantri, S.H,. ML. Ed Erman Rajagukguk dan Ridwan Khairandy) (Jakarta: Universitas Indonesia Press, 2001), hlm. 495.

12 Koesnadi Hardjasoemantri, "Aspek Hukum Peran Serta Masyarakat dalam Pengelolaan Lingkungan Hidup", dalam Abdul Gofur Anshori dan Sobirin Malian, Membangun Hukum Indonesia Pidato Pengukuhan Guru Besar Ilmu Hukum, (Yogyakarta: Kresi Total Media, 2008), hlm. 146 - 148. 
oleh Pemerintah dan dapat meningkatkan kualitas keputusan tersebut.

b. Meningkatkan kesediaan masyarakat untuk menerima keputusan

Seseorang warga masyarakat yang telah memperoleh kesempatan untuk berperan serta dalam proses pengambilan keputusan dan tidak dihadapkan pada suatu fait accompli, akan cenderung untuk memperlihatkan kesediaan yang lebih besar guna menerima dan menyesuaikan diri dengan keputusan tersebut. Peran serta masyarakat dalam proses pengambilan keputusan akan dapat banyak mengurangi timbulnya pertentangan, asal peran serta tersebut dilaksanakan pada saat yang tepat. Bahwa suatu keputusan tidak pernah akan memuaskan semua kepentingan, semua golongan atau semua warga masyarakat, namun kesediaan masyarakat untuk menerima keputusan Pemerintah akan dapat ditingkatkan.

\section{c. Membantu Perlindungan Hukum}

Apabila sebuah keputusan akhir diambil dengan memperhatikan keberatan-keberatan yang diajukan oleh masyarakat selama proses pengambilan keputusan berlangsung, maka dalam banyak hal tidak akan ada keperluan untuk mengajukan perkara ke pengadilan. Apabila sebuah perkara diajukan ke pengadilan, maka lazimnya perkara tersebut memusatkan diri pada suatu kegiatan tertentu. Dengan demikian tidak dibuka kesempatan untuk menyarankan dan mempertimbangkan alternatif kegiatan lainnya.

\section{d. Mendemokratisasikan Pengambilan}

Keputusan

Ada pendapat yang menyatakan, bahwa dalam pemerintahan dengan sistem perwakilan, maka hak untuk melaksanakan kekuasaan ada pada wakil-wakil rakyat. Dengan demikian tidak ada keharusan adanya bentuk-bentuk dariperan serta masyarakat karena wakil-wakil rakyat itu bertindak untuk kepentingan rakyat.

Pendapat lainnya yang mengatakan bahwa dalam sistem perwakilan, peran serta masyarakat dalam pengambilan keputusan administratif akan menimbulkan masalah keabsahan demokratis, karena warga masyarakat, kelompok atau organisasi yang turut serta dalam proses pengambilan keputusan tidaklah dipilih atau diangkat secara demokratis. Terhadap kritik di atas tersebut, Guindling mengemukakan tanggapannya, yaitu:

a. Bahwa demokrasi dengan sistem perwakilan adalah satu bentuk demokrasi, bukan satusatunya;

b. Bahwa sistem perwakilan tidak menutup bentuk-bentuk demokrasi langsung; dan

c. Bahwa bukanlah warga masyarakat, sekelompok warga masyarakat atau organisasi yang sesungguhnya mengambil keputusan, mereka hanya berperan serta dalam tahap-tahap persiapan pengambilan keputusan.

Selanjutnya menurut Koesnadi Hardjasoemantri, ada beberapa persyaratan untuk guna mendayagunakan dan menghasilgunakan peran serta masyarakat dalam pengelolaan lingkungan hidup, sebagai berikut: ${ }^{13}$

a. Pemimpin yang eksekutif yang terbuka;

b. Peraturan yang akomodatif;

c. Masyarakat yang sadar lingkungan;

d. Lembaga Swadaya Masyarakat (LSM) yang tanggap; 
e. Informasi yang tepat; dan

f. Keterpaduan.

Pemberdayaan masyarakat yang difasilitasi oleh pemerintah dapat menjadi sebuah instrumen yang digunakan untuk meningkatkan pengelolaan dan pemanfaatan hutan yang berdayaguna bagi masyarakat itu sendiri. Masyarakat dapat mengetahui dampak dari perbuatan mereka dan mencari solusi dari apa yang mereka perbuat, sehingga masyarakat dapat melindungi, menjaga pelestarian hutan dimana tempat menggantungkan hidup.

Masyarakat memiliki hak dan kesempatan yang sama dan seluas-luasnya untuk berperan aktif dalam perlindungan dan pengelolaan lingkungan hidup. Peran masyarakat dapat berupa: a) pengawasan sosial; b) pemberian saran, pendapat, usul, keberatan, pengaduan; dan/atau penyampaian informasi dan/atau laporan. Adapun peran masyarakat dilakukan untuk: ${ }^{14}$

a. Meningkatkan kepedulian dalam perlindungan dan pengelolaan lingkungan hidup;

b. Meningkatkan kemandirian, keberdayaan masyarakat dan kemitraan;

c. Menumbuhkembangkanketanggapsegeraan masyarakat untuk melakukan pengawasan sosial; dan

d. Mengembangkan dan menjaga budaya dan kearifan lokal dalam rangka pelestarian fungsi lingkungan.

\section{Perlindungan dan Pengelolaan Hutan}

Perbuatan dan tindakan pengelolaan dan pemanfaatan hutan satu sisi akan memberikan manfaat yang besar bagi umat manusia (masyarakat). Namun apabila perbuatan (pengelolaan dan pemanfaatan) itu dilakukan sebaliknya akan menimbulkan kerusakan, maka hal itu tidak akan membawa manfaat atau menimbulkan kerugian bagi umat manusia. ${ }^{15}$ Dalam hal pemanfaatan hutan diperlukan konsep pengelolaan berdasarkan prinsip berkelanjutan (sustainable forest management) dan dibutuhkan perlindungan hutan agar hutan dapat berfungsi dengan baik. ${ }^{16}$

Pasal 47 UU Kehutanan 1999, disebutkan bahwa perlindungan hutan dan kawasan hutan merupakan usaha untuk (1) mencegah dan membatasi kerusakan hutan, kawasan hutan dan hasil hutan yang disebabkan oleh perbuatan manusia, ternak, kebakaran, daya-daya alam, hama serta penyakit; dan (2) mempertahankan dan menjaga hak-hak negara, masyarakat dan perorangan atas hutan, kawasan hutan, hasil hutan, investasi serta perangkat yang berhubungan dengan pengelolaan hutan.

Pasal 7 Peraturan Pemerintah Nomor 45 Tahun 2004 tentang Perlindungan Hutan, menyebutkan untuk mencegah, membatasi kerusakan hutan, kawasan hutan dan hasil hutan yang disebabkan oleh perbuatan manusia, maka Pemerintah, Pemerintah Daerah dan Masyarakat:

14 Pasal 70 ayat (1), (2) dan (3) Undang-Undang Nomor 32 Tahun 2009 tentang Perlindungan dan Pengelolaan Lingkungan Hidup.

15 Suriansyah Murhanini, Hukum Kehutanan Penegakan Hukum Terhadap Kejahatan di Bidang Kehutanan, Cetakan II ( Yogjakarta: Laksbang Grafika, 2012), hlm. 11.

16 Tujuan perlindungan hutan adalah untuk menjaga kelestarian dan fungsi hutan, serta menjaga mutu, nilai dan kegunaan hasil hutan. Pasal 46 UU Kehutanan 1999, menyebutkan bahwa perlindungan hutan adalah agar fungsi hutan yang meliputi fungsi lindung, fungsi konservasi dan fungsi produksi dapat tercapai secara optimal dan lestari. 
a. Melakukan sosialisasi dan penyuluhan peraturan perundang-undangan di bidang kehutanan;

b. Melakukan inventarisasi permasalahan;

c. Mendorong peningkatan produktivitas masyarakat;

d. Memfasilitasi terbentuknya kelembagaan masyarakat;

e. Meningkatkan peran serta masyarakat dalam kegiatan pengelolaan hutan;

f. Melakukan kerjasama dengan pemegang hak atau izin;

g. Meningkatkan efektifitas koordinasi kegiatan perlindungan hutan;

h. Mendorong terciptanya alternatif mata pencaharian masyarakat;

i. Meningkatkan efektifitas pelaporan terjadinya gangguan keamanan hutan;

j. Mengambil tindakan pertama yang diperlukan terhadap gangguan keamanan hutan; atau

k. Mengenakan sanksi terhadap pelanggaran hukum.

Aspek-aspek kunci pembangunan berkelanjutan meliputi pemberdayaan masyarakat lokal, swasembada dan keadilan sosial. ${ }^{17}$ Salah satu usaha untuk mencapai hal tersebut adalah berpindah dari bentuk tradisional pengelolaan lingkungan dan sumber daya. Selama ini didominasi oleh ahli professional dari sektor pemerintah dan swasta, menuju pendekatan yang mengkombinasikan pengalaman, pengetahuan dan pemahaman berbagai kelompok masyarakat. Konsepsi kemitraan dan kelompok kepentingan (stakeholders) selalu digunakan untuk mencirikan sebuah pendekatan yang menyertakan baik kelompok kepentingan maupun publik secara luas dalam perencanaan lingkungan dan sumber daya.

Dalam hal ini, pengelolaan bersama adalah pengelolaan yang meliputi pembagian kekuasaan yang sesungguhnya antara pengelola pada tingkat lokal dan pemerintah, sehingga masing-masing dapat mengontrol penyimpangan yang dilakukan oleh pihak lain. ${ }^{18}$ Dengan kata lain pengelolaan bersama sumber daya alam di sektor kehutanan merupakan merefleksikan bentuk-bentuk kemitraan antara pemerintah yang diberi kewenangan untuk melakukan pengurusan dan pengaturan pengelolaan dan pemanfaatan sumber daya alam di sektor kehutanan dan di tingkat lokal (baca: masyarakat) diberikan hak otonomi untuk mengelola hutan dengan tradisi/budaya yang hidup di pada tingkat lokal tersebut.

Pengelolaan hutan pada dasarnya adalah suatu bentuk kegiatan usaha yang dilakukan dalam rangka memperoleh manfaat hutan dan hasil hutan menurut peraturan perundangundangan yang berlaku. Bentuk pengelolaan hutan dibagi ke dalam 2 (dua) bagian, yaitu: ${ }^{19}$

a. Pengelolaan hutan negara yaitu, suatu bentuk kegiatan usaha yang dilaksanakan Pemerintah atau Badan Hukum yang ditunjuk dalam rangka memperoleh manfaat hutan dan hasil hutan di kawasan hutan negara, berdasarkan peraturan perundangundangan yang berlaku. 
b. Pengelolaan hutan rakyat yaitu, suatu bentuk kegiatan usaha yang dilakukan orang atau badan hukum dalam rangka memperoleh manfaat hutan dan hasil hutan, diatas tanah milik atau hak lainnya, berdasarkan peraturan perundang-undangan yang berlaku.

Pasal 11 ayat (2) UU Kehutanan 1999, menyatakan bahwa perencanaan kehutanan dilaksanakan secara transparan, bertanggung-gugat, partisipatif, terpadu, serta memperhatikan kekhasan dan aspirasi daerah. Pasal 42 ayat (2) UU Kehutanan 1999, yang mengatur tentang rehabilitasi hutan dan lahan, juga menyatakan bahwa penyelenggaraan rehabilitasi hutan dan lahan diutamakan pelaksanaannya melalui pendekatan partisipatif dalam rangka mengembangkan potensi dan memberdayakan masyarakat.

Pasal 43 ayat (2) UU Kehutanan 1999, menyebutkan setiap orang dapat meminta pendampingan, pelayanan dan dukungan kepada lembaga swadaya masyarakat, pihak lain atau pemerintah. Selanjutnya Pasal 48 ayat (2) UU Kehutanan 1999, bahwa untuk menjamin pelaksanaan perlindungan hutan maka masyarakat diikutsertakan dalam upaya tersebut. Masyarakat juga dapat berperan serta dalam pengawasan kehutanan. Pasal 62 UU Kehutanan 1999, Pemerintah, Pemerintah Daerah dan masyarakat melakukan pengawasan terhadap pengelolaan dan/atau pemanfaatan hutan yang dilakukan oleh pihak ketiga. Dan ditambahkan lagi oleh Pasal 64 UU Kehutanan 1999, bahwa Pemerintah dan masyarakat melakukan pengawasan terhadap pelaksanaan pengelolaan hutan yang berdampak nasional dan internasional.

Partisipasi masyarakat adalah keterlibatan masyarakat dalam melakukan kegiatan pencegahan dan pemberantasan perusakan hutan memiliki peran yang sangat siginifikan dalam rangka menjaga kelestarian hutan. Pasal 58 Undang-Undang Nomor 18 Tahun 2013 tentang Pencegahan Pemberantasan Perusakan Hutan, menyebutkan Masyarakat berhak atas:

a. Lingkungan hidup yang baik dan sehat termasuk kualitas lingkungan hidup yang dihasilkan oleh hutan;

b. Pemanfaatan hutan sesuai dengan ketentuan peraturan perundang-undangan;

c. Upaya pemberdayaan masyarakat; dan

d. Penyuluhan tentang pentingnya kelestarian hutan dan dampak negatif perusakan hutan. Selain hak sebagaimana disebutkan di atas, dalam rangka pencegahan dan pemberantasan perusakan hutan, masyarakat berhak:

a. Mencari dan memperoleh informasi adanya dugaan telah terjadinya perusakan hutan;

b. Mendapat pelayanan dalam mencari, memperoleh dan memberikan informasi adanya dugaan telah terjadi perusakan hutan dan penyalahgunaan izin kepada penegak hukum;

c. Mencari dan memperoleh informasi terhadap izin pengelolaan hutan yang telah dikeluarkan oleh pemerintah daerah setempat;

d. Menyampaikan saran dan pendapat secara bertanggung jawab kepada penegak hukum; dan

e. Memperoleh perlindungan hukum dalam;

- Melaksanakan haknya sebagaimana dimaksud dalam huruf $a$, huruf $b$ dan huruf c; dan

- Proses penyelidikan, penyidikan dan persidangan sebagai saksi pelapor, saksi atau saksi ahli sesuai dengan ketentuan peraturan perundang-undangan. 
Selanjutnya, Masyarakat berkewajiban:

a. Menjaga dan memelihara kelestarian hutan; dan

b. Mengelola hutan sesuai dengan ketentuan peraturan perundang-undangan.

Masyarakat berkewajiban memberikan informasi, baik lisan maupun tulisan kepadapihak yang berwenang apabila mengetahui atau adanya indikasi perusakan hutan.

Masyarakat berperan serta dalam pencegahan dan pemberantasan perusakan hutan dengan cara:

a. Membentuk dan membangun jejaring sosial gerakan anti perusakan hutan;

b. Melibatkan dan menjadi mitra lembaga pemberantasan perusakan hutan dalam kegiatan pencegahan dan pemberantasan perusakan hutan;

c. Meningkatkan kesadaran tentang pentingnya kelestarian hutan dan dampak negative perusakan hutan;

d. Memberikan informasi, baik lisan maupun tulisan kepada pihak yang berwenang berkaitan dengan pencegahan dan pemberantasan perusakan hutan;

e. Ikut serta melakukan pengawasan dalam penegakan hukum pemberantasan perusakan hutan; dan/atau

f. Melakukan kegiatan lain yang bertujuan untuk pencegahan dan pemberantasan perusakan hutan.

Dalam hal lembaga yang menangani pemberantasan perusakan hutan melakukan kemitraan dengan organisasi atau lebaga swadaya masyarakat yang bergerak di bidang kehutanan atau di bidang lingkungan serta organisasi sosial kemasyarakatan dalam melakukan pendampingan, pelayanan dan dukungan kepada masyarakat.

Hal yang juga perlu diperhatikan dalam pengorganisasian pengelolaan pemberdayaan masyarakat adalah adanya partisipasi aktif dari masyarakat. Secara sederhana partisipasi masyarakat dapat diartikan sebagai upaya terencana untuk melibatkan masyarakat dalam setiap proses terencana untuk melibatkan masyarakat dalam setiap proses kegiatan yang dilakukan dari mulai perencanaan sampai kepada kegiatan monitoring dan evaluasi. ${ }^{20}$ Partisipasi masyarakat juga merupakan suatu proses dimana masyarakat sebagai obyek dan subyek yang akan memperoleh dampak (positif dan/atau negatif) ikut mempengaruhi arah dan pelaksanaan kegiatan, tidak hanya sekedar menerima hasilnya.

Beberapa faktor yang mempengaruhi partisipasi masyarakat dalam pengelolaan pemberdayaan masyarakat antara lain yaitu: ${ }^{21}$

a. Mobilitas penduduk yang tinggi, hal tersebut akan menurunkan partisipasi masyarakat.

b. Kesempatan kerja di luar desa yang luas, menurunkan partisipasi.

c. Luas lahan garapan; semakin luas semakin rendah partisipasinya.

d. Produksi usaha tani yang semakin tinggi; semakin tinggi; semakin rendah partisipasinya.

e. Insentif dan bantuan pemerintah yang semakin lengkap, maka semakin tinggi partisipasi masyarakat.

f. Lokasi lahan; semakin jauh dan sulit semakin rendah partisipasinya. 
g. Pendapatan semakin tinggi; semakin tinggi pula partisipasinya.

Pengelolaan hutan membutuhkan sebuah perencanaan yang melibatkan seluruh kelompok kepentingan yang bertujuan memperoleh apa yang di cita-citakan bersama. Peran pemerintah yang begitu besar dalam pengelolaan hutan dituntut lebih pro aktif dan terbuka dalam melakukan pendampingan, pelayanan dan dukungan kepada masyarakat.

\section{Pemberdayaan Masyarakat di Sekitar Hutan Lindung Pulau Tarakan}

Pengelolaan hutan merupakan salah satu upaya penting yang harus dilakukan oleh Pemerintah Kota Tarakan dalam rangka mewujudkan visi yang dicanangkan yaitu mewujudkan "Tarakan sebagai Kota Pusat pelayanan, perdagangan dan jasa yang berbudaya, sehat, adil, sejahtera dan berkelanjutan.

Peraturan Daerah Nomor 4 Tahun 2012 tentang Rencana Tata Ruang Wilayah Kota Tarakan Tahun 2012-2032, menetapkan luasan hutan Lindung Kota Tarakan adalah 6997 hektar Kondisi ini tentu membawa dampak baik terhadap kelangsungan hidup jangka panjang masyarakat secara umum, karena dengan kawasan hutan yang cukup luas dan produktif sesuai fungsinya, maka beberapa faktor bencana bisa dicegah. Termasuk banjir, ketersedian air bersih hingga udara segar yang dihasilkan oleh tanaman atau pohon-pohon yang tumbuh di hutan secara alami.

Akan tetapi di sisi lain, terdapat kendalakendala yang menyebabkan kurang produktifnya fungsi hutan tersebut, yang disebabkan oleh ulah masyarakat sendiri. Seperti pembalakan kayu hutan dan penyerobotan kawasan hutan untuk kepentingan perorangan, tak jarang pula, masyarakat yang merasa memiliki lahan di dalam kawasan hutan lindung, akan bersikukuh untuk mempertahankannya, sehingga terjadi kesenggangan antara pihak pemerintah daerah (Dinas Kehutanan Pertambangan dan Energi), dengan kelompok masyarakat yang berkepentingan tersebut, baik itu mereka yang menggarap hutan untuk pertanian maupun yang memanfaatkannya sebagai pemukiman.

Solusi yang digunakan untuk mengurangi kesenggangan tersebut ialah dengan Pemberdayaan masyarakat di sekitar hutan lindung. Bertujuan untuk:

a. Menciptakan kondisi kehidupan sosial disekitar hutan yang kondusif.

b. Mencegah meningkatnya perambahan hutan dan pencurian kayu.

c. Salah satu upaya solusi masalah konflik lahan, dan

d. Pelestarian sumber daya hutan

Adapun implementasi dari pemberdayaan masyarakat di sekitar hutan lindung ialah dengan dikeluarkannya Peraturan Pemerintah Nomor 6 Tahun 2007 tentang Tata Hutan dan Penyusunan Rencana Pengelolaan Hutan, Serta Pemanfaatan Hutan. Untuk mendapatkan manfaat sumber daya hutan secara optimal dan adil, dilakukan pemberdayaan masyarakat setempat melalui pengembangan kapasitas dan pemberian akses dalam rangka peningkatan kesejahteraan.Pemberdayaan masyarakat setempat merupakan kewajiban Pemerintah, Provinsi, Kabupaten/Kota yang pelaksanaannya menjadi tanggung jawab kepala Kesatuan Pengelolaan Hutan (KPH).

Pasal 84 Peraturan Pemerintah Nomor 6 Tahun 2007 tentang Tata Hutan dan Penyusunan Rencana Pengelolaan Hutan, Serta Pemanfaatan Hutan, Pemberdayaan masyarakat setempat, 
dapat dilakukan melalui: a) hutan desa; b) hutan kemasyarakatan; dan c) kemitraan.

\section{a. Hutan Desa}

Hutan desa dapat diberikan pada hutan lindung dan hutan produksi. Areal kerja hutan desa ditetapkan oleh Menteri Kehutanan berdasarkan usulan Bupati atau Walikota sesuai kritreria yang ditentukan dan rencana pengelolaan yang disusun oleh Kepala Kesatuan Pengelolaan Hutan atau pejabat yang ditunjuk. Pemberdayaan masyarakat setempat melalui hutan desa dilakukan dengan memberikan hak pengelolaan kepada lembaga desa, dapat meliputi kegiatan tata areal, penyusunan rencana pengelolaan areal, pemanfaatan hutan serta rehabilitasi dan perlindungan hutan.

Pasal 87 ayat (3) Peraturan Pemerintah Nomor 6 Tahun 2007 tentang Tata Hutan dan Penyusunan Rencana Pengelolaan Hutan Serta Pemanfaatan Hutan, Pemanfaatan hutan desa yang berada pada:

1) Hutan Lindung, meliputi kegiatan pemanfaatan kawasan, pemanfaatan jasa lingkungan, pemungutan hasil hutan bukan kayu; dan

2) Hutan Produksi, meliputi kegiatan pemanfaatan hasil hutan kayu dan bukan kayu, pemungutan hasil hutan kayu dan bukan kayu.

Dalam memberikan hak pengelolaan hutan kepada lembaga desa, Pemerintah, Pemerintah Provinsi atau PemerintahKabupaten/Kota sesuai dengan kewenangannya memberikan fasilitasi yang meliputi pengembangan kelembagaan, pengembangan usaha, bimbingan teknologi, pendidikan dan latihan, serta akses terhadap pasar. Berdasarkan penetapan areal kerja hutan desa fasilitasi menteri, memberikan izin usaha pemungutan hasil hutan kayu dalam hutan desa dengan tembusan kepada Gubernur, Bupati atau Walikota dan Kepala Kesatuan Pengelolaan Hutan, sedang Gubernur, selain memberikan fasilitasi memberikan hak pengelolaan hutan desa.

Hak pengelolaan hutan desa bukan merupakan hak kepemilikan atas kawasan hutan dan dilarang memindahtangankan atau mengagunkan, serta mengubah status dan fungsi kawasan hutan. Kawasan hutan yang ditetapkan sebagai hutan desa dilarang digunakan untuk kepentingan lain di luar rencana pengelolaan hutan dan harus dikelola berdasarkan prinsip pengelolaan hutan lestari.

Lembaga desa sebagai pemegang hak pengelolaan hutan desa, wajib melaksanakan pengelolaan hutan, sesuai dengan prinsipprinsip pengelolaan hutan lestari yang dituangkan dalam Peraturan Desa. Lembaga desa menyusun rencana pengelolaan hutan atau pejabat yang ditunjuk sebagai bagian dari rencana pengelolaan hutan. Lembaga desa menyusun rencana pengelolaan hutan desa bersama kepala kesatuan pengelolaan hutan atau pejabat yang ditunjuk sebagai bagian dari rencana pengelolaan hutan.

Pasal 91 ayat (2) Peraturan Pemerintah Nomor 6 Tahun 2007 tentang Tata Hutan dan Penyusunan Rencana Pengelolaan Hutan Serta Pemanfaatan Hutan, lembaga desa sebagai pemegang hak pengelolaan hutan desa wajib:

1) Menyusun rencana kerja hak pengelolaan hutan desa selama jangka waktu berlakunya hak pengelolaan hutan desa;

2) Melaksanakan penataan batas hak pengelolaan hutan desa;

3) Melakukan perlindungan hutan; dan

4) Melaksankan penatausahaan hasil hutan. 


\section{R Ruenal HTS VINDING}

Media Pembinaan Hukum Nasional

\section{b. Hutan Kemasyarakatan}

Berdasarkan Undang-Undang Nomor 5 Tahun 1967 tentang Ketentuan-Ketentuan Pokok Kehutanan, kemudian diganti dengan Undang-Undang Nomor 41 Tahun 1999 yang direvisi dengan Perpu Nomor 1 Tahun 2004 dan Peraturan Pemerintah Nomor 21 Tahun 1970 tentang Hak Pengusahaan Hutan dan Hak Pemungutan Hasil Hutan, maka pengusahaan hutan negara dikawasan Hutan Produksi dilakukan oleh Badan Usaha Milik Negara dan/ atau bersama Perusahaan Swasta yang ditunjuk. Dari prinsip inilah yang disebut dalam beberapa Keputusan Menteri Kehutanan sebagai Hutan Kemasyarakatan. Sistem hutan kemasyarakatan tersebut sebenarnya disusun dengan itikad baik, dengan menyerahkan pengelolaan sumber daya hutan kepada masyarakat dan bersifat berkelanjutan.

Pemberdayaan masyarakat melalui hutan kemasyarakatan, dapat diberikan pada: a) hutan konservasi, kecuali cagar alam dan zona inti taman nasional, b) hutan lindung; dan hutan produksi. Areal kerja hutan kemasyarakatan ditetapkan oleh Menteri Kehutanan atas usulan Bupati atau Walikota berdasarkan permohonan masyarakat setempat sesuai rencana pengelolaan yang disusun oleh Kepala Kesatuan Pengelolaan Hutan atau pejabat yang ditunjuk.

Pemberdayaan masyarakat setempat melalui hutan kemasyarakatan, dilakukan melalui pemberian izin usaha pemanfaatan hutan kemasyarakatan. Izin usaha pemanfatan hutan kemasyarakatan, yang berada pada:

1) Hutan lindung, meliputi kegiatan pemanfaatan kawasan, pemanfaatan jasa lingkungan, pemungutan hasil hutan bukan kayu.

2) Hutan produksi, meliputi kegiatan pemanfaatan kawasan, pemanfaatan jasa lingkungan, pemanfaatan hasil hutan kayu dan bukan kayu, pemungutan hasil hutan kayu dan bukan kayu.

Dalam memberikan izin pemanfaatan hutan kemasyarakatan, Pemerintah, Pemerintah Provinsi dan Pemerintah Kabupaten/Kota sesuai kewenangannya memberikan fasilitasi yang meliputi pengembangan kelembagaan, pengembangan usaha, bimbingan teknologi, pendidikan dan latihan, akses terhadap pasar serta pembinaan dan pengendalian.

Berdasarkan penetapan areal kerja, Menteri Kehutanan memberikan izin usaha pemanfaatan hasil hutan kayu dalam hutan kemasyarakatan pada areal kerja hutan kemasyarakatan, dengan tembusan kepada Gubernur, Bupati atau Walikota dan Kepala Kesatuan Pengelolaan Hutan, sedangkan Gubernur memberikan izin pada areal kerja hutan kemasyarakatan lintas kabupaten atau kota yang ada dalam wilayah kewenangannya dan Bupati atau Walikota, pada areal kerja hutan kemasyarakatan yang ada dalam wilayah kewenangannya memberikan izin usaha pemanfaatan hutan kemasyarakatan, yang meliputi kegiatan usaha pemanfaatan kawasan, penanaman tanaman hutan berkayu, pemanfaatan jasa lingkungan, pemanfaatan hasil hutan kayu dan bukan kayu dan pemungutan hasil hutan kayu dan bukan kayu.

Izin usaha pemanfaatan hutan kemasyarakatan dapat diberikan kepada kelompok masyarakat setempat, pemegang izin usaha pemanfaatan hutan kemasyarakatan selain melaksanakan kegiatan pemanfaatan hutan, wajib melaksanakan pengelolaan hutan sesuai dengan prinsip-prinsip pengelolaan hutan lestari, dan diberikan untuk jangka waktu 35 (tiga puluh lima) tahun dan dapat diperpanjang.

Izin usaha pemanfaatan hutan kemasyarakatan bukan merupakan hak kepemilikan 
atas kawasan hutan dan dilarang memindahtangankan atau mengagunkan serta mengubah status dan fungsi kawasan hutan dan kawasan hutan yang ditetapkan untuk hutan kemasyarakatan, dilarang digunakan untuk kepentingan lain di luar rencana pengelolaan dan harus dikelola berdasarkan prinsip-prinsip pengeloaan hutan lestari.

\section{c. Kemitraan}

Pasal 99 Peraturan Pemerintah Nomor 6 Tahun 2007 tentang Tata Hutan dan Penyusunan Rencana Pengelolaan Hutan Serta Pemanfaatan Hutan, Pemberdayaan masyarakat setempat dapat dilaksanakan melalui kemitraan, dalam hal: a) Kawasan hutan yang bersangkutan telah diberikan izin pemanfaatan hutan; dan Kawasan hutan yang bersangkutan telah diberikan hak pengelolaan hutan kepada badan usaha milik Negara (BUMN) bidang kehutanan.

Menteri, Gubernur atau Bupati/Walikota sesuai kewenangannya, wajib memfasilitasi terbentuknya kemitraan antara masyarakat setempat dengan pemegang izin usaha pemanfaatan hutan atau pemegang hak pengelolaan hutan.Kemitraan dapat dilakukan berdasarkan kesepakatan antara pemegang izin pemanfaatan hutan atau kemitraan hak pengelolaan dengan masyarakat setempat.Dan pemberdayaan masyarakat setempat melalui kemitraan tidak mengubah kewenangan dari pemegang izin pemanfaatan hutan atau pemegang hak pengelolaan kepada masyarakat.

Peraturan Menteri Kehutanan Nomor P.39/Menhut-II/2013 tentang Pemberdayaan Masyarakat setempat Melalui Kemitraan Kehutanan adalah upaya untuk meningkatkan kemampuan dan kemandirian masyarakat setempat untuk mendapatkan manfaat sumber daya hutan secara optimal dan adil melalui kemitraan kehutanan dalam rangka peningkatan kesejahteraan masyarakat setempat.

Kemitraan Kehutanan adalah kerjasama antara masyarakat setempat dengan Pemegang Izin pemanfaatan hutan atau Pengelola Hutan, Pemegang Izin usaha industri primer hasil hutan, dan/atau Kesatuan Pengelolaan Hutan dalam pengembangan kapasitas dan pemberian akses dengan prinsip kesetaraan dan saling menguntungkan. Adapun maksud pemberdayaan masyarakat melalui Kemitraan Kehutanan adalah mengembangkan kapasitas dan memberikan akses masyarakat setempat dalam rangka kerjasama dengan Pemegang Izin Pemanfaatan hutan atau Pengelola Hutan, Pemegang izin usaha industri primer hasil hutan, dan/atau Kesatuan Pengelolaan Hutan wilayah tertentu untuk meningkatkan kemandirian dan kesejahteraan masyarakat setempat. Sedangkan tujuan pemberdayaan masyarakat setempat melalui kemitraan kehutanan adalah terwujudnya masyarakat setempat untuk mendapatkan manfaat secara langsung, melalui penguatan kapasitas dan pemberian akses, ikut serta dalam mewujudkan pengelolaan hutan lestari, dan secara bertahap dapat berkembang menjadi pelaku ekonomi yang tangguh, mandiri, bertanggung jawab dan profesional.

Pemberdayaan masyarakat setempat melalui Kemitraan Kehutanan harus menggunakan prinsip-prinsip:

1) Kesepakatan: semua masukan, proses dan keluaran Kemitraan Kehutanan dibangun berdasarkan kesepakatan antara para pihak dan bersifat mengikat.

2) Kesetaraan: para pihak yang bermitra mempunyai kedudukan hukum yang sama dalam pengambilan keputusan. 
3) Saling menguntungkan: para pihak yang bermitra berupaya untuk mengembangkan usaha yang tidak menimbulkan kerugian.

4) Lokalspesifik:kemitraankehutanan dibangun dan dikembangkan dengan memperhatikan budaya dan karakteristik masyarakat setempat, termasuk menghormati hak-hak tradisional masyarakat adat.

5) Kepercayaan: kemitraan kehutanan dibangun berdasarkan rasa saling percaya antar para pihak

6) Transparansi: masukan, proses dan keluaran pelaksanaan kemitraan kehutanan dijalankan secara terbuka oleh para pihak, dengan tetap menghormati kepentingan masing-masing pihak.

7) Partisipasi: pelibatan para pihak secara aktif, sehingga setiap keputusan yang diambil memiliki legitimasi yang kuat.

\section{Adapun persyaratan dalam program} kemitraan kehutanan ialah:

1) Luasan areal kemitraan kehutanan paling luas 2 (dua) hektar untuk setiap keluarga.

2) Dalam hal masyarakat setempat bermitra untuk memungut hasil hutan bukan kayu atau jasa lingkungan hutan luasan sebagaiaman dimaksud pada ayat (1) tidak berlaku

3) Masyarakat setempat calon mitra Pengelola Hutan dan Pemegang Izin harus memenuhi persyaratan:

- Masyarakat setempat yang berada di dalam dan/atau disekitar areal Pengelola Hutan dan Pemegang Izin dibuktikan dengan Kartu Tanda Penduduk (KTP) atau Surat Keterangan tempat tinggal dari kepala desa setempat;

Mempunyai mata pencaharian pokok bergantung pada lahan garapan/ pungutan hasil hutan non kayu di areal sebagaimana dimaksud pada huruf a; dan

- Mempunyai potensi untuk pengembangan usaha secara berkelanjutan.

\section{Penutup}

Dari uraian di atas dapat disimpulkan kegiatan pemberdayaan masyarakat disekitar hutan lindung Pulau Tarakan mempunyai peran yang sangat strategis dalam pencegahan dan pemberantasan kerusakan hutan untuk menjaga kelestarian hutan lindung pulau Tarakan. Keterlibatan masyarakat di sekitar hutan lindung pulau Tarakan dapat dilakukan dengan memperluas jaringan dengan komunitas masyarakat yang bergerak dibidang lingkungan hidup, sumber daya alam dan kehutanan, meningkatkan kesadaran masyarakat disekitar hutan lindung pulau Tarakan, ikut dalam pengambilan keputusan dengan pemerintah daerah dalam pengelolaan dan perlindungan hutan Lindung Pulau Tarakan dan ikut melakukan pengawasan dalam penegakan hukum di bidang kehutanan. Dan pemberdayaan masyarakat disekitar hutan lindung Pulau Tarakan merupakan kewajiban pemerintah daerah yang pelaksanaannya menjadi tanggung jawab kepala Kesatuan Pengelolaan Hutan, pemberdayaan masyarakat setempat, dapat dilakukan melalui: a) hutan desa; b) hutan kemasyarakatan dan c) kemitraan.

Dan dari penelitian ini direkomendasikan melakukan perubahan pendekatan kepada pemberdayaan masyarakat dengan memberikan akses dan selalu melibatkan masyarakat dalam setiap pengambilan kebijakan hal ini terbukti dapat mengurangi konflik antara masyarakat dan pemerintah. Selanjutnya pemerintah daerah sesuai dengan kewenanganya menyiapkan 
norma hukum yang lebih responsif untuk melindungi setiap hak-hak dan jaminan sosial dan ekonomi masyarakat yang ada di dalam wilayah hutan lindung Pulau Tarakan. Perlunya sosialisasi peraturan perundang-undangan dibidang lingkungan hidup dan kehutanan oleh sumber daya manusia yang profesional dan partisipasi para pihak atau kelompok yang berkepentingan dalam program pemberdayaan masyarakat di dalam dan sekitar hutan.

\section{Daftar Pustaka}

\section{Buku}

Ahmad Redi, Hukum Sumber Daya Alam Dalam Sektor Kehutanan (Jakarta: Sinar Grafika, 2014).

Anshori, Abdul Gofur dan Sobirin Malian, Membangun Hukum Indonesia Pidato Pengukuhan Guru Besar Ilmu Hukum (Yogyakarta: Kresi Total Media, 2008).

Erman Rajagukguk dan Ridwan Khairandy, ed., Hukum dan Lingkungan Hidup Di Indonesia 75 Tahun Prof. Dr. Koesnadi Hardjasoemantri, S.H,. ML. (Jakarta: Universitas Indonesia Press, 2001).

Hadin Muhjad, Hukum Lingkungan Sebuah Pengantar Untuk Konteks Indonesia (Yogyakarta: Genta Publishing, 2015).

Maria S.W. Sumardjono. Et al., Pengaturan Sumber Daya Alam Di Indonesia Antara Yang Tersurat Dan Tersirat Kajian Kritis Undang-Undang Terkait Penataan Ruang dan Sumber Daya Alam (Yogyakarta: Fakultas Hukum Universitas Gadjah Mada bekerja sama dengan Universitas Gadjah Mada Press, 2011).

Mitchell, Bruce. et al., Pengelolaan Sumber Daya dan Lingkungan (Yogjakarta: Gajah Mada University, 2010).

Piter Mahmud Marzuki, Penelitian Hukum (Jakarta: Penerbit Prenada Media, 2005).

Suriansyah Murhanini, Hukum Kehutanan Penegakan Hukum Terhadap Kejahatan di Bidang Kehutanan, (Yogjakarta: Laksbang Grafika, 2012).
Wahidin, Samsul. Dimensi Hukum Perlindungan dan Pengelolaan Lingkungan Hidup, Yogyakarta: Pustaka Pelajar, 2014.

\section{Makalah/Artikel/Prosiding/Hasil Penelitian}

Ubbe, Ahmad. et al., "Penelitian Hukum Tentang Peran Serta Masyarakat Hukum Adat Dalam Penanggulangan Pembalakan Liar" (Jakarta: Pusat Penelitian dan Pengembangan Sistem Hukum Nasional Badan Pembinaan Hukum Nasional Kementerian Hukum dan Hak Asasi Manusia RI, 2013).

Warasih, Esmi, "Pemberdayaan Masyarakat Dalam Mewujudkan Tujuan Hukum (Proses Penegakan Hukum dan Persoalan Keadilan)" (Pidato disampaikan pada Pengukuhan Guru Besar Madya Dalam Ilmu Hukum Pada Fakultas Hukum Universitas Diponegoro, Semarang, 14 April 2001).

Dinas Kehutanan, Pertambangan \& Energi Kota Tarakan dengan Lembaga Penelitian dan Pengabdian Kepada Masyarakat (LPPM) UBT, "Tata Hutan Wilayah Kelola KPHL Tarakan" (Tarakan: Kerjasama antara, 2011).

\section{Peraturan}

Undang-Undang Nomor 18 Tahun 2013 tentang Pencegahan Pemberantasan Perusakan Hutan

Undang-Undang Nomor 32 Tahun 2009 tentang Perlindungan dan Pengelolaan Lingkungan Hidup

Undang-Undang Nomor 41 Tahun 1999 tentang Kehutanan

Peraturan Pemerintah Nomor 6 Tahun 2007 tentang Tata Hutan dan Penyusunan Rencana Pengelolaan Hutan

Peraturan Pemerintah Nomor 45 Tahun 2004 tentang Perlindungan Hutan

Peraturan Menteri Kehutanan Nomor P.39/Menhut. II/2013 tentang Pemberdayaan Masyarakat Setempat Melalui Kemitraan Kehutanan.

Peraturan Daerah Nomor 4 Tahun 2012 tentang Rencana Tata Ruang Wilayah Kota Tarakan Tahun 2012-2032 